\title{
電子䛜折法による格子常数決定の精度について
}

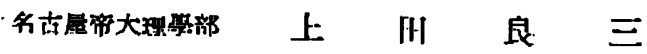 \\ (昭和十九年一月甘九日受理)
}

はしがこの研究は管子趣折法によつて決是

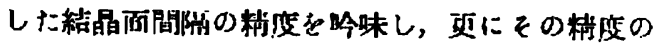

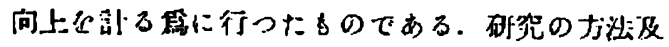

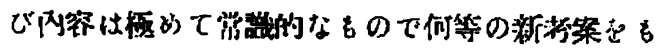
合んで斿ないのが、㐫れられ省みられない米柄

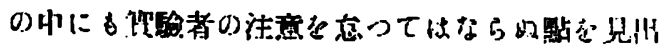

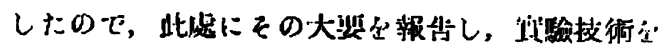

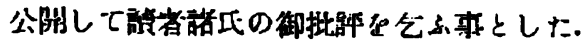

\section{1. 原理及び会式}

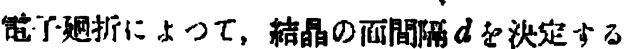
に蜙式

$$
2 d \sin \theta=\lambda
$$

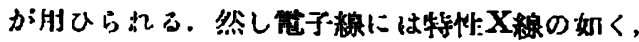
波長が一定で月っその濒が正確に知られた6のか～

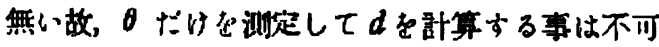

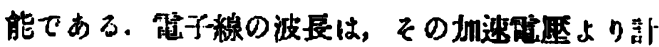

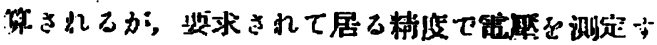

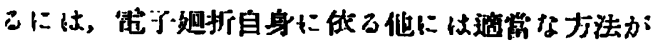

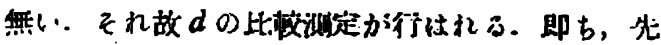

第一略

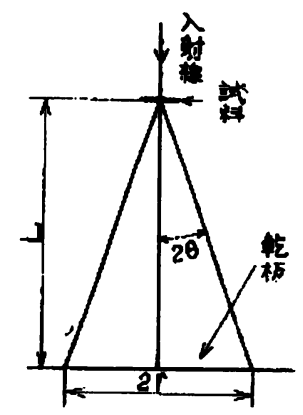

つ格子管敖の知的れた

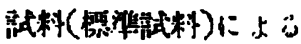

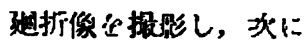

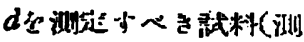
定践料) に琶 き换一兀

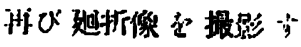

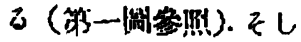
て前者心 $\theta$ 上り入或

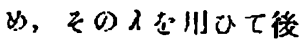
孝のd部第するので

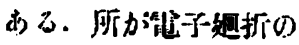

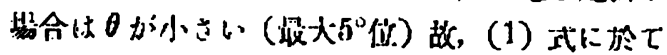

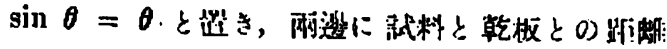
I. 岕け

$$
\mathrm{r} d=\lambda \mathrm{I} \text {. }
$$

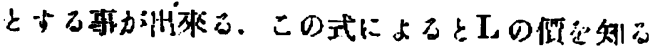

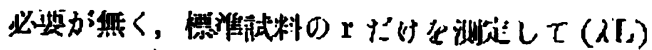

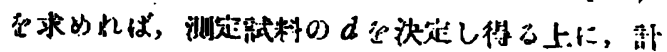

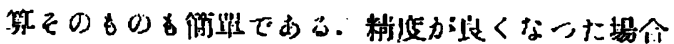

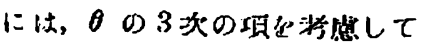

$$
\begin{gathered}
\mathrm{r} d(1-\varepsilon)=\lambda \mathrm{I}, \\
\dot{\varepsilon}=\frac{3}{8}\left(\frac{\mathrm{r}}{\mathrm{L}}\right)^{2}
\end{gathered}
$$

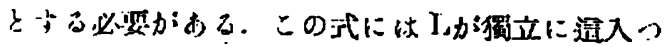

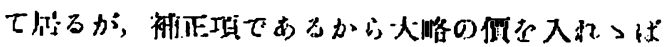
立分である.

\section{2. 氧釷崭置及び測定}

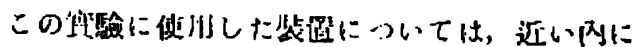

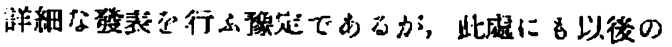

$$
\text { 第二圆 (1) }
$$

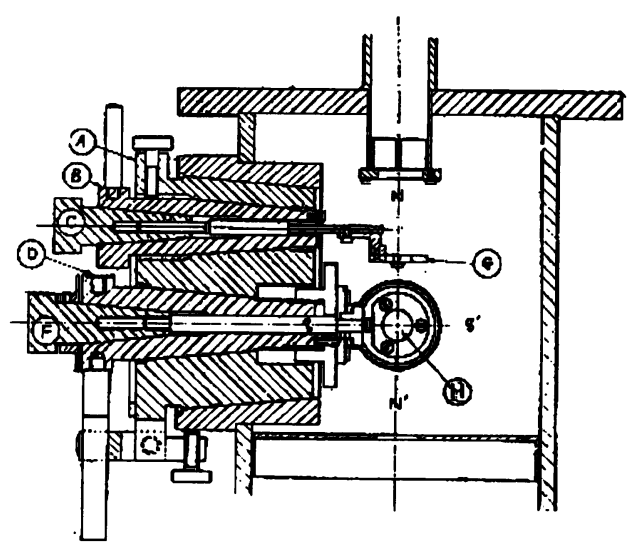

(a)

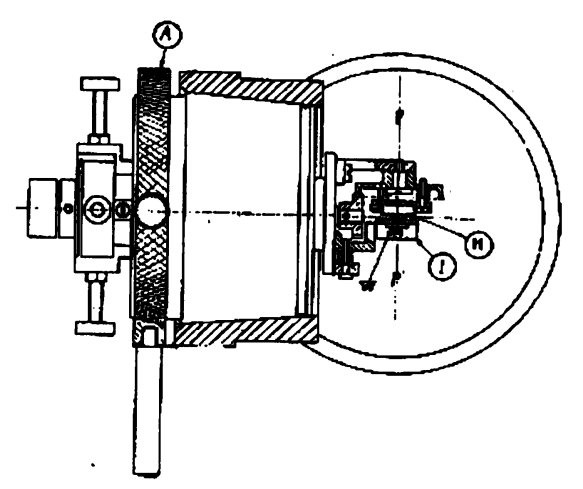




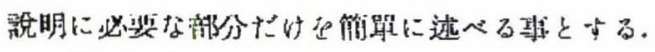

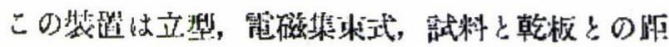
灉 $150 \mathrm{~mm}$ と云ふ小型なるのである.

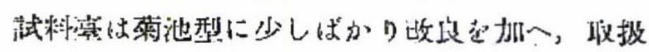

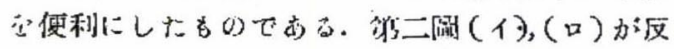

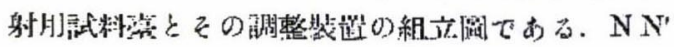
か人射線の厅间て，試料は(H)のボタンの上に侔

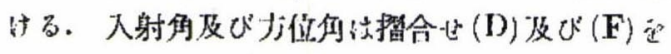

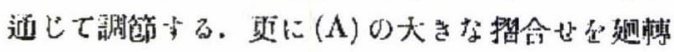

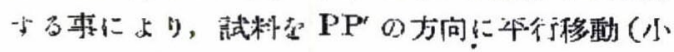

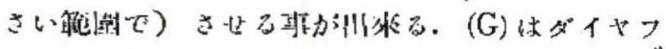

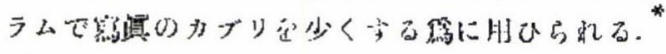

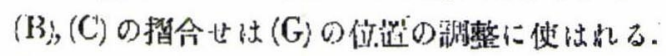

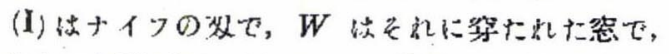

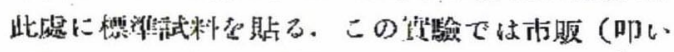

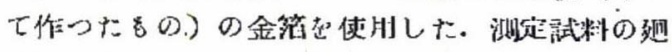

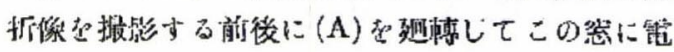

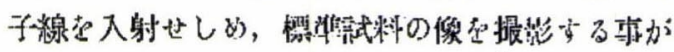
出來る。

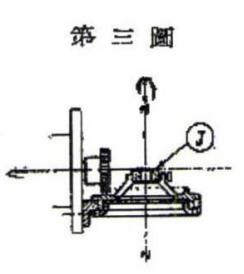

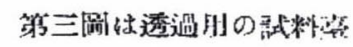
で,こ机は第二阔の㴬川

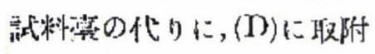

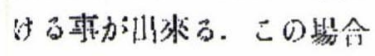
に快(I)）の摺命せによのて

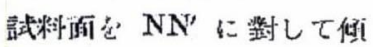

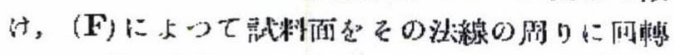

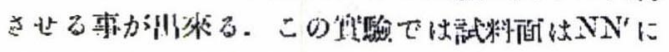

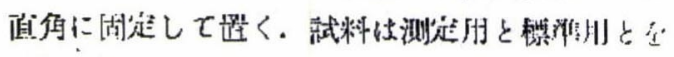

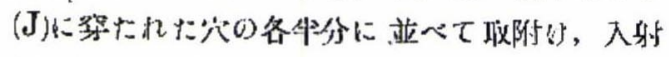

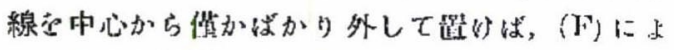

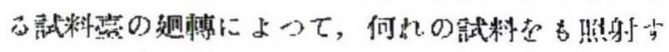

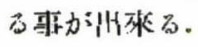

乾板仙 $4 \times 12 \mathrm{~cm}$ ，(中啡の三分の一）で，一凄

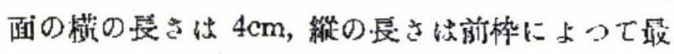

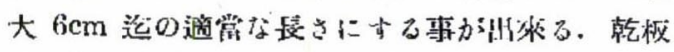

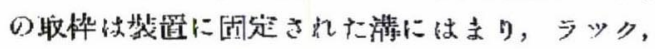

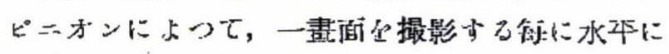
移動させる. 一乾板上の書而の数仗，その大さに

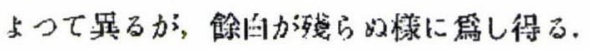

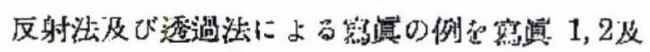

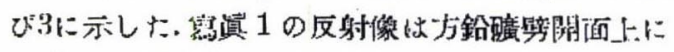

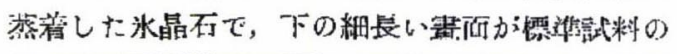

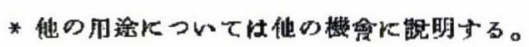

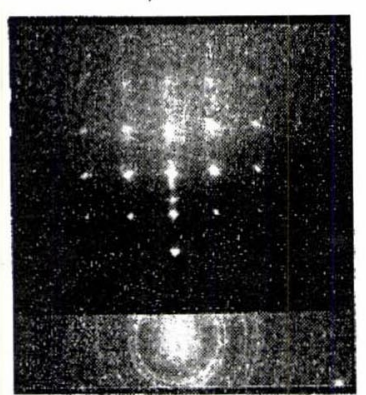

䉥路 1

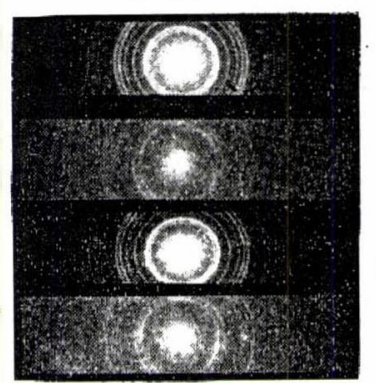

怒 踶 2

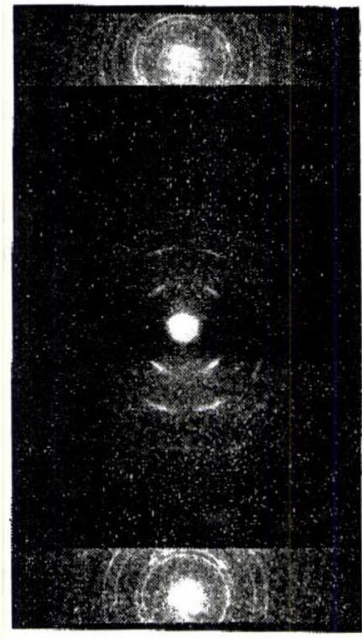

紫调
金销によるものて あ) る.この才式心 高心粆度走望求し な心普通の测迟に

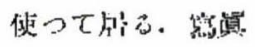
2 は陖化恶鎦及で

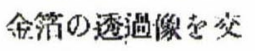
名に撮影した方い の中办二回分店 叹り玳して心した きので, 之は酸化

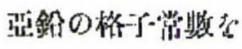

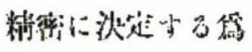
に掫影したもので dる. 等蒖 3 は"

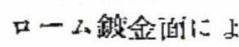
及反的僟である か，入射點泪时定0)

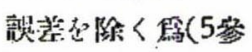
照), 二回の撮影 行行りたのであ あ.上下の細長い

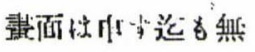
く金䇴によるもの

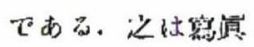

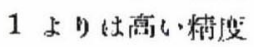
盁目橙として行り

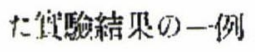
である。

繁是 1 及心゙ 30 如人測定当可可點

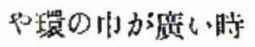
约, 原墨堭約 3 倍

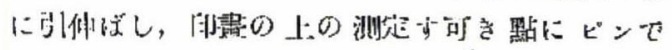

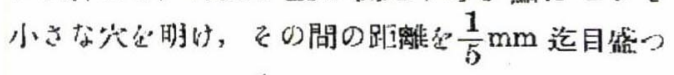

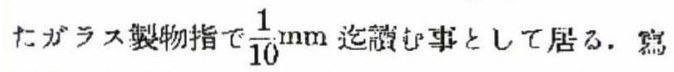

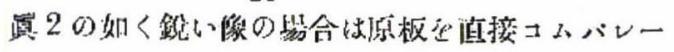

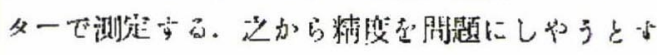

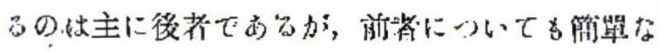
說明究附好版一る事とした。

\section{3. גI の決定}

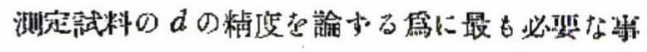




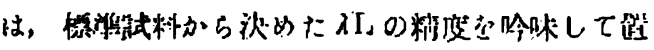
く亦である。

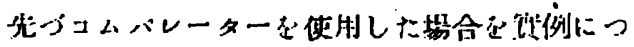

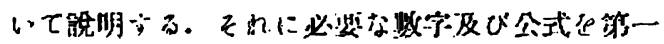

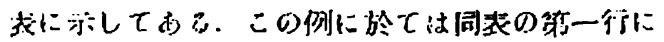

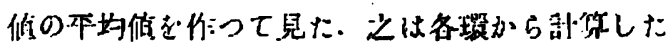

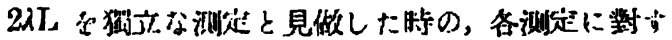

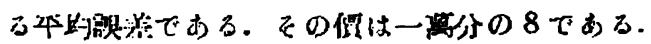

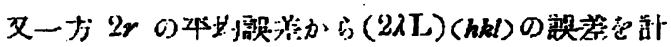

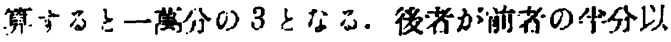

\begin{tabular}{|c|c|c|c|c|c|c|c|c|}
\hline 1 & $(k k l)$ & $(111)$ & $(200)$ & $(220)$ & $(311)$ & $(3: 31)$ & $(420)$ & $(422)$ \\
\hline 2 & $2 \gamma(\mathrm{mm})$ & 8.268 & 9 & 1.2 .493 & 15.790 & $2 n .824$ & 21.344 & 23.379 \\
\hline 3 & $\delta / 2 r \times 10^{3}$ & 0.7 & $0 . \pi$ & 1.1 & 0.6 & 0.7 & 0.7 & 0.4 \\
\hline 1 & $\varepsilon \times 10^{8}$ & $0 . .3$ & 0.4 & 0.8 & 1.0 & 1.8 & 1.4 & 2.3 \\
\hline 5 & $d(A)$ & 2.3494 & $2.02 r_{n} n$ & $1.4: 390$ & 1.2271 & 0.043 .7 & 0.9100 & 0.8308 \\
\hline 6 & $2 \lambda L(A \cdot u n)$ & 19.423 & $19.38 . ?$ & $\mid:-403$ & 19.355 & 191.111 & 19.8.8) & 19.387 \\
\hline 7 & $\Delta / 2 \pi L_{2} \times 10^{8}$ & +1.5 & -0.5 & +0.5 & -1.9 & +0.5 & -0.1 & -()$. ?$ \\
\hline \multicolumn{4}{|c|}{ 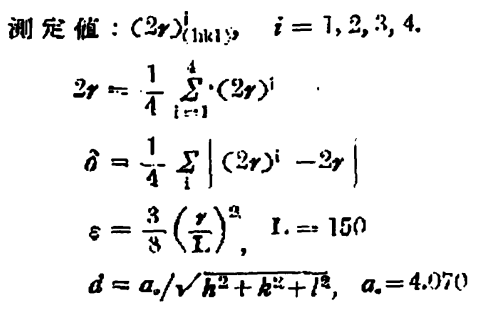 } & & \multicolumn{4}{|c|}{ 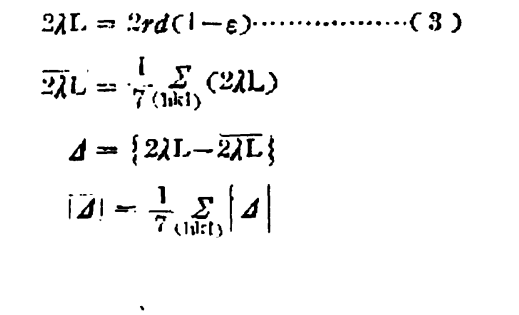 } \\
\hline & $3 \pi \mathrm{L}=19.393$ & $\begin{array}{l}|\bar{d}| \\
|\bar{\Delta}|\end{array}$ & 6 & $\frac{1}{\sqrt{7}}$ & $=0.0006$ & & & \\
\hline
\end{tabular}

靯

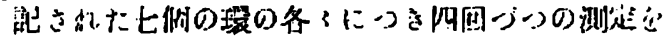

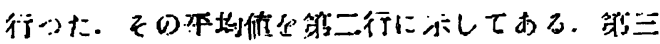

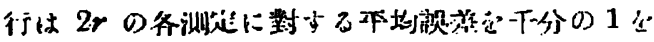

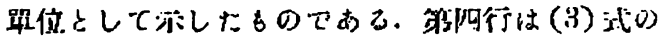

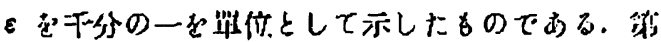

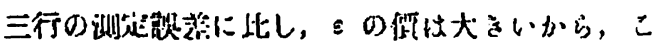

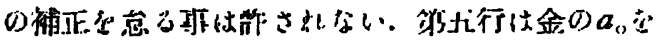

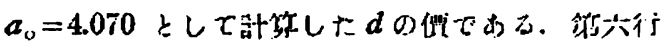

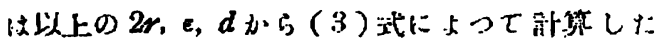

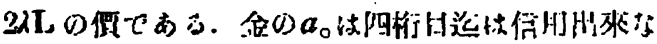

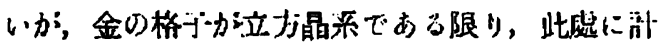

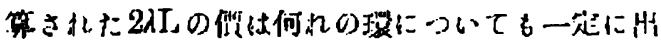

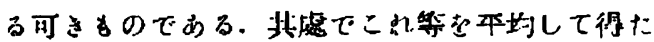

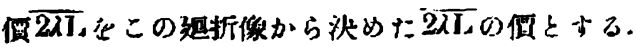

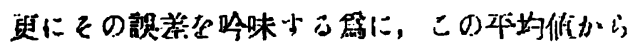

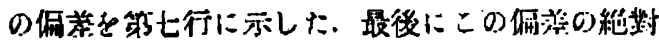

ドでする或が統計ひ不足にあるか，或ひは物理的

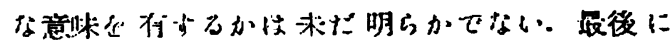

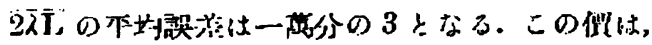

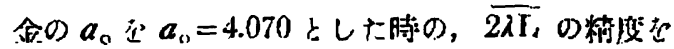
就目安と邦へられる。

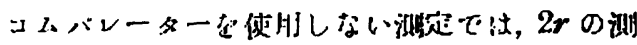

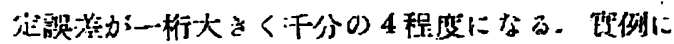

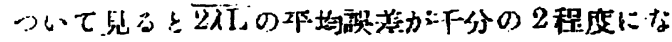
のてる。.

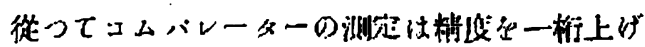
た本になるわけである。

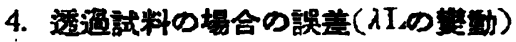

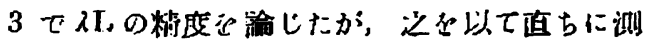

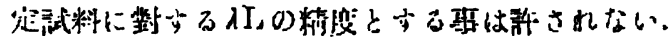

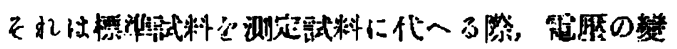




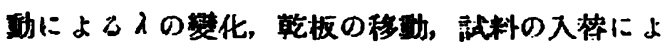
こしの變化か起るからである。この中,活然の變動

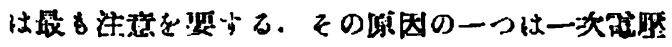

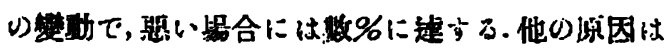

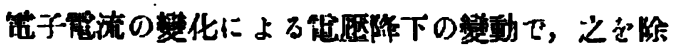

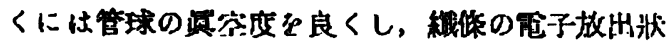

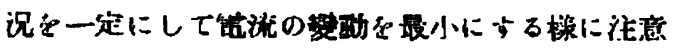

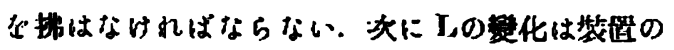

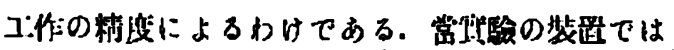

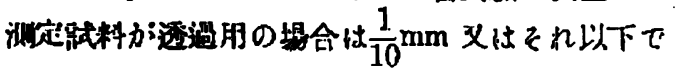

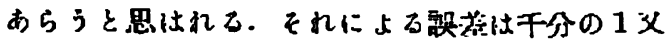
はをれ以下てあるから引仪的畫による测定では開 題とならないが、コムバレーターによる训定の晹

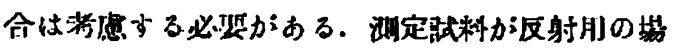
合は詯身に不碓定な所があるのて，5で詳しく 速凶る束とする。

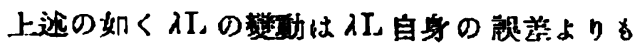
迤に大きいものである。この影整を除く雼には，

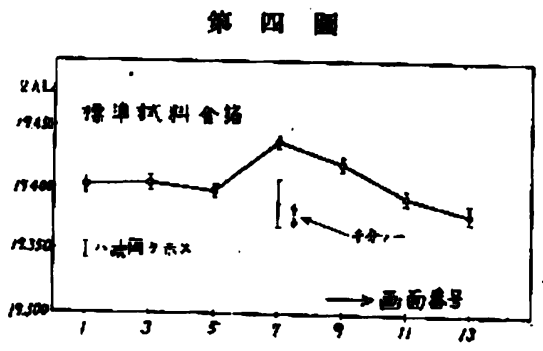

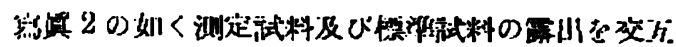

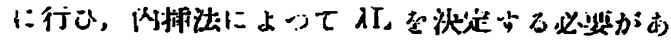

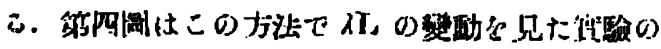

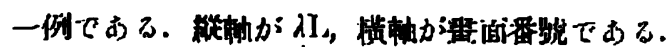

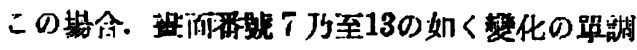

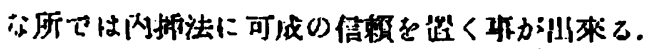

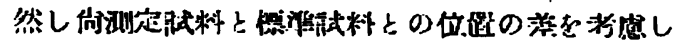

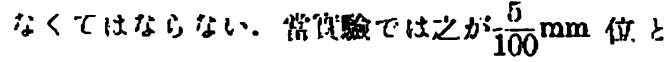

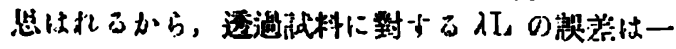
黄分の 5 位に見精门れる。

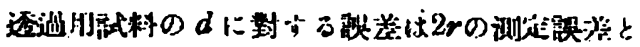

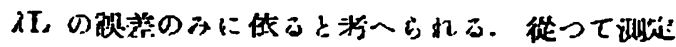

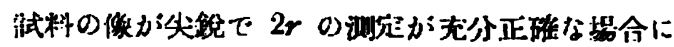

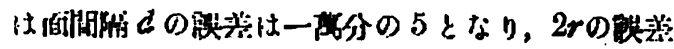

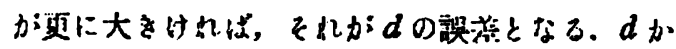

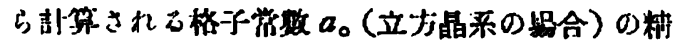

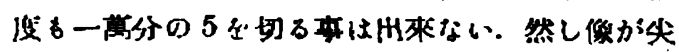

銳であれば粗比は更に正確に決め得る。

\section{5. 反讨坮料の场合の媄盖}

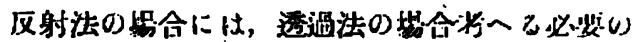
無かつた臹学の原因が二つある。

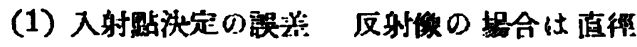

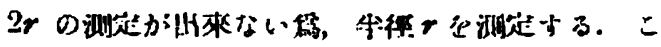

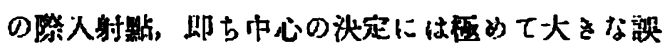

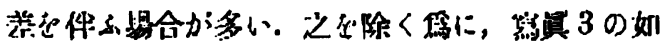

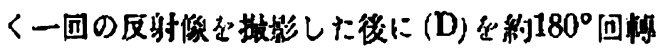

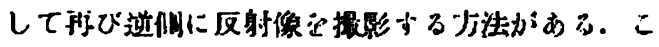

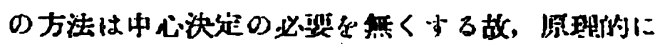

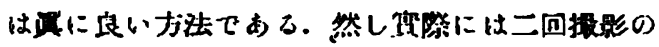

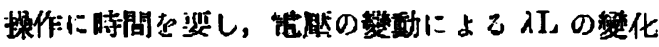

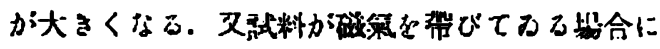

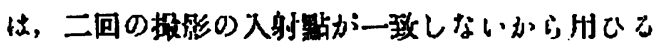
事が出來ない，就料に磁性力無い塔合でも，(D) と

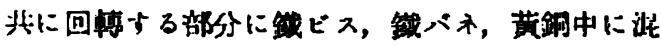
入した鐵愿等が们れば同核の結果になる。從つて

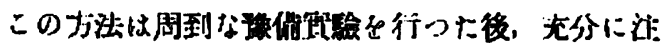

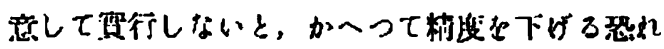
がある。

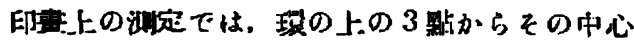

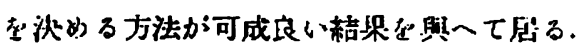

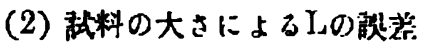

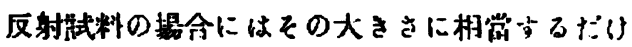

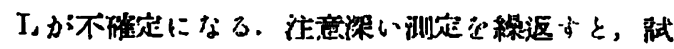

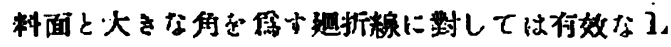

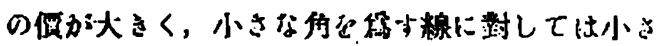

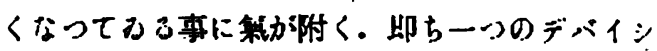

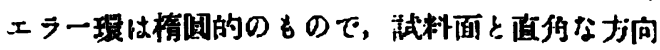

第五圆

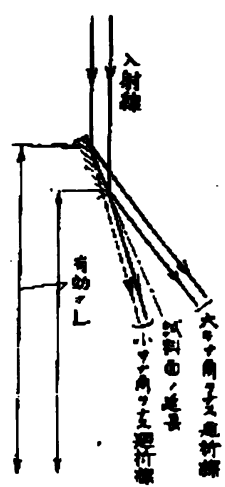

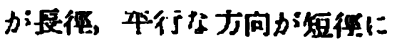
なつて居る。艾大きな理と小

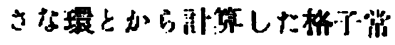
数 $\boldsymbol{a}_{0}$ (立方晶系の等合) 化 枚けると，朤者か後者よりる

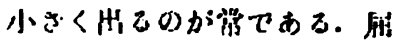
折效果も之と同楼な倾向尔示 †かZnOの然の如く，用折效

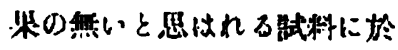

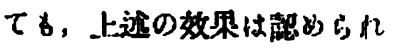

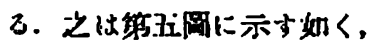

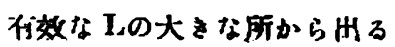




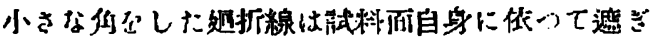

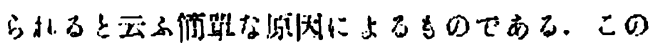

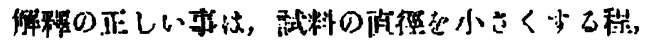

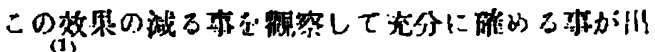
米た。

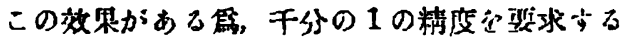
ならは，

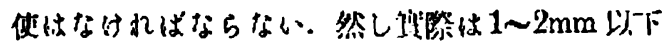

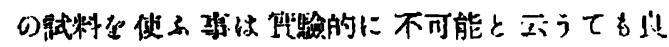
い大さな呲料使って Iの

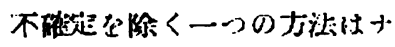
イフの观 (I) 践料而に充分 に近附学て，その先の所だけ が週折に们效になる栐に古る 束である。然しこのオ法休末 块庭行して愿ない.此處では

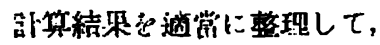

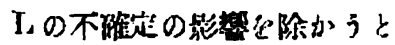

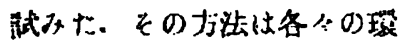

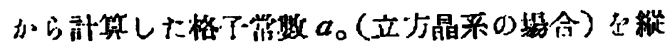

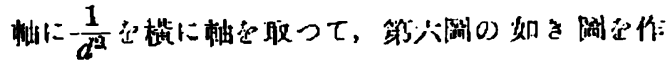

第 枀婟

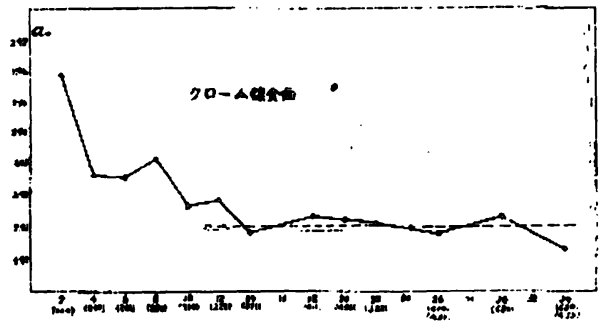

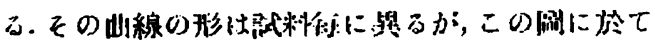

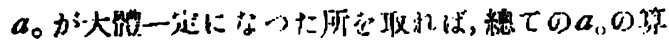

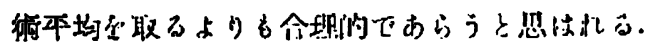

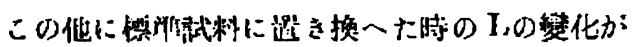

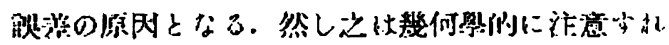

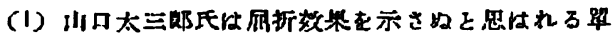

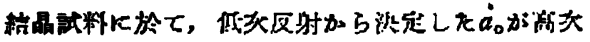

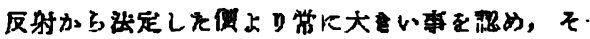

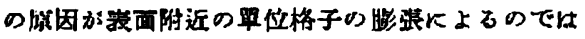

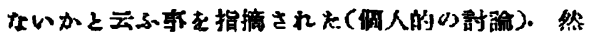
し程々の點を特合すると，との原因は有效なI，の

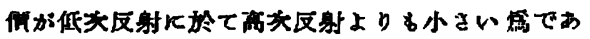
ると丰のる方が合理的らしく思はれる。

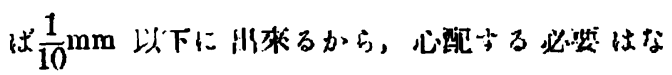
6.

以」:逝へた如く反射法の努合は透週法に比して

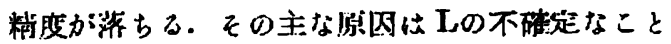

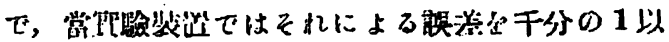
下にする本は不可能でする，又反射の槡合は印書。

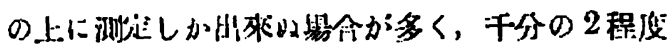

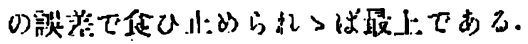

积二 棐

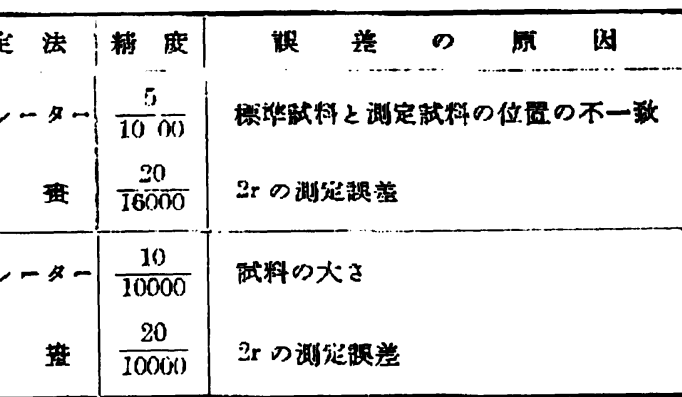

\section{6. 精庋向上の方法}

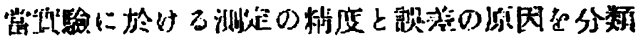

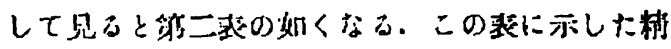

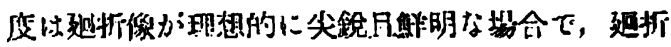

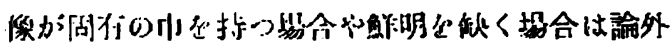

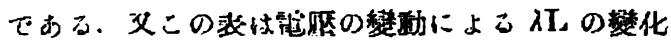

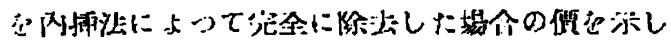

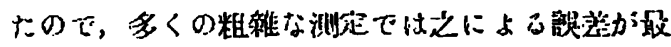

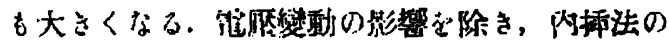

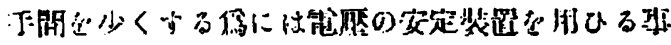
加算ましい。

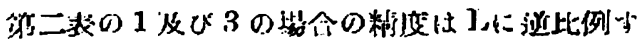

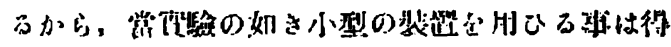

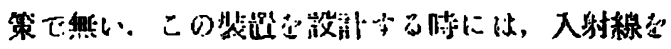

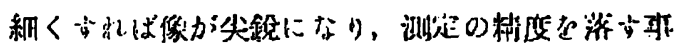

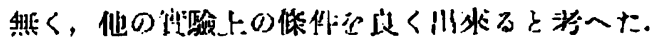

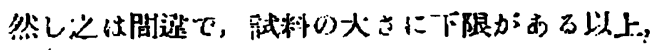

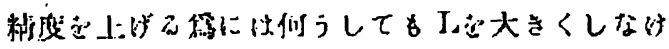

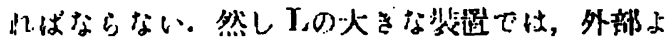

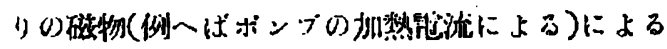

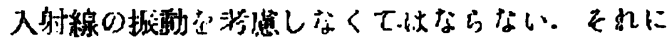

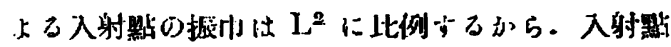

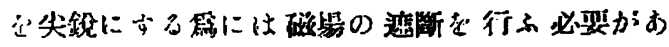

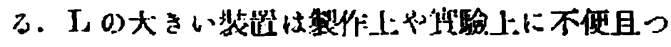

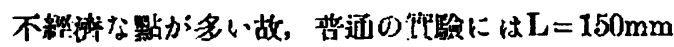




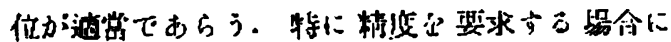

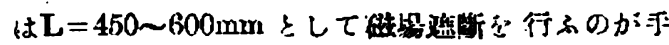
昍な設䂥では無いかと思はれる。

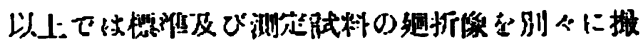

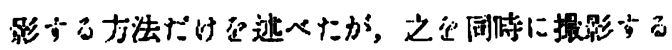

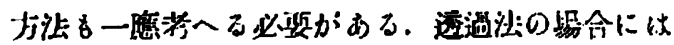

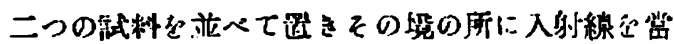

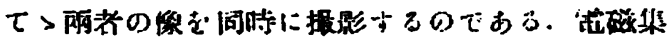

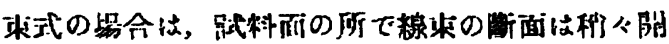
いて居るから，この师法も不可能で岾ない。然

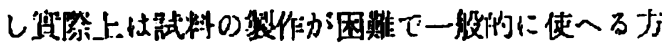

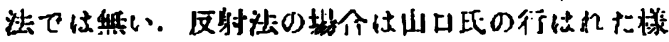

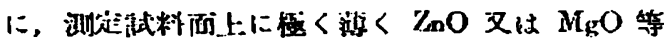

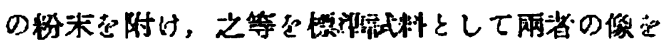

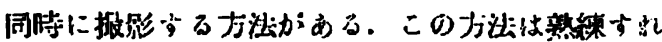

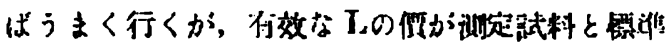

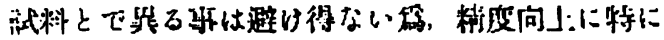
们效だとは思はれない。

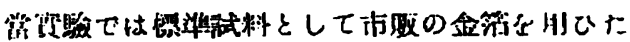

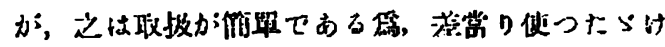

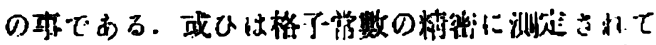

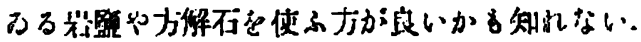

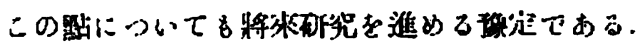

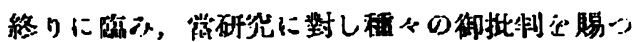

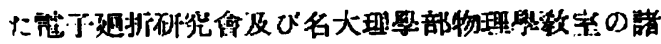

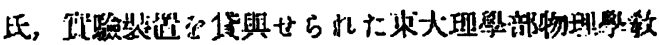

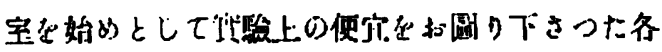

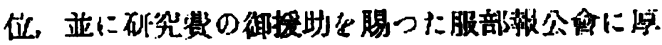

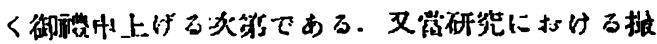

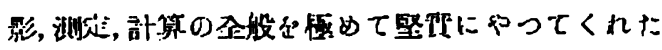

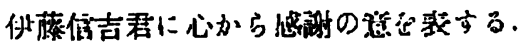

